AKUNTABILITAS

Vol. VIII No. 3, Desember 2015

P-ISSN : 1979-858X

Halaman. 238 - 253

\title{
PENGARUH MANAJEMEN LABA TERHADAP PENGUNGKAPAN CORPORATE SOCIAL RESPONSIBILITY: VARIABEL ANTESEDEN DAN VARIABEL MODERASI
}

\author{
Gita Mustika \\ Ria Nelly Sari ${ }^{1}$ \\ Al Azhar L
}

Program Studi S1 Akuntansi, Fakultas Ekonomi, Universitas Riau

\begin{abstract}
The purpose of this study is to examine the effect of audit quality on earning management and the effect of earning management on the corporate social responsibility disclosure. In addition, this study also examine moderating role of accounting complexity and effectiveness of audit committee on relationship between earning management and corporate social responsibilty disclosure. The population in this study are manufacturing companies listed in Indonesia Stock Exchange for the 2013 financial year and purposive sampling is used as sampling method. Sample in this study is 6o manufacturing companies. This study uses secondary data which is obtained from company's annual report. Statistical method used is Structural Equation Model (SEM) based on Partial Least Square (PLS). The result prove that audit quality negatively affect the earning management, and earning management positively affect the corporate social responsibility disclosure. The result also prove that accounting complexity and effectiveness of audit committee weaken the effect of earning management on corporate social responsibilty.
\end{abstract}

Keywords: Quality Audit, Earning Management, Accounting Complexity, Effectiveness Of Audit Committee, And Corporate Social Responsibility.

ABSTRAK: Penelitian ini bertujuan untuk mengetahui pengaruh kualitas audit terhadap manajemen laba dan pengaruh manajemen laba terhadap pengungkapan corporate social responsibility. Selain itu, penelitian ini juga menguji peran kompleksitas akuntansi dan efektifitas komite audit sebagai pemoderasi hubungan antara manajemen laba dan pengungkapan corporate social responsibility. Populasi dalam penelitian ini adalah seluruh perusahaan manufaktur yang terdaftar di BEI pada tahun 2013. Metode sampling yang digunakan adalah purpoisve sampling method, sehingga diperoleh 6o perusahaan manufaktur yang menjadi sampel. Penelitian ini menggunakan data sekunder diperoleh dari laporan tahunan (Annual Report) perusahaan. Metode statistik yang digunakan Structural Equation Model (SEM) berbasis Partial Least Square (PLS). Hasil Penelitian ini membuktikan bahwa kualitas audit berpengaruh negatif terhadap manajemen laba dan manajemen laba berpengaruh positif terhadap corporate social responsibility. Penelitian ini juga membuktikan bahwa kompleksitas akuntansi dan efektifitas komite audit berperan dalam memperlemah hubungan antara manajemen laba dan pengungkapan corporate social responsibility.

Kata kunci : Kualitas Audit, Manajemen Laba, Kompleksitas Akuntansi, Efektifitas Komite Audit, dan Pengungkapan Corporate Social Responsibility

\footnotetext{
${ }^{1}$ Draft pertama: 04 September 2015; Revisi: 12 Oktober 2015; Diterima: 19 November 2015

Penulis dapat dikontak melalui: ria_n_sari@yahoo.com
} 


\section{PENDAHULUAN}

Menghadapi dampak globalisasi, kemajuan teknologi informasi, dan keterbukaan pasar, perusahaan harus secara serius dan terbuka memperhatikan pengungkapan tanggung jawab sosial. Saat ini tanggung jawab perusahaan harus berpijak pada triple bottom lines yaitu tanggung jawab perusahaan pada aspek sosial, lingkungan, dan ekonomi sehingga setiap perusahaan diwajibkan untuk mengungkapkan informasi tentang tanggung jawab sosial perusahaan atau Corporate Social Responsibility (CSR).

Pengungkapan tanggung jawab sosial merupakan salah satu upaya yang dilakukan perusahaan untuk dapat memenuhi kepentingan stakeholders dan menjamin keberlangsungan perusahaan jangka panjang. Pengungkapan informasi perusahaan dapat dipandang sebagai cara untuk mempengaruhi persepsi prospek keuangan perusahaan di masa depan oleh pihak eksternal terutama stakeholder, seperti analis saham, pelaku pasar modal, dan investor institusional (Brammer dan Pavelin, 2006).

CSR berkembang seiring dengan semakin parahnya kerusakan lingkungan yang terjadi di Indonesia maupun dunia. Fenomena ini menyadarkan masyarakat di dunia bahwa sumber daya alam adalah terbatas dan oleh karenanya pembangunan ekonomi harus dilaksanakan secara berkelanjutan (sustainable development). Sejalan dengan perkembangan tersebut di Indonesia, Undang-Undang No. 40 Tahun 2007 tentang Perseroan Terbatas mewajibkan semua perseroan untuk melaporkan pelaksanaan tanggung jawab tersebut di laporan tahunan. Namun walaupun aturan tentang kewajiban CSR sudah jelas, pengawasan atas pelaksanaan CSR belum ada. Hal ini menimbulkan keberagaman bentuk dan tingkat intensitas pelaksanaan CSR yang bervariasi pada perusahaanperusahaan di Indonesia, serta menyebabkan tidak jelasnya jumlah pengeluaran untuk kegiatan CSR karena tinggi rendahnya pengungkapan tidak disertai bukti atas pengeluaran kegiatan.

Untuk memberikan apresiasi terhadap perusahaan yang telah menyelenggarakan laporan berkelanjutan (sustainability report), baik yang diterbitkan secara terpisah maupun terintegrasi dalam laporan tahunan (annual report). Pada tahun 2005 Ikatan Akuntan Indonesia dan National Center for Sustainability Reporting (NCSR), mengadakan sebuah event penghargaan Indonesia Sustainability Reporting Award (ISRA). Event ini berlangsung setiap tahunnya hingga saat sekarang ini.

ISRA adalah penghargaan yang diberikan kepada perusahaan - perusahaan yang telah membuat pelaporan atas kegiatan yang menyangkut aspek lingkungan dan sosial disamping aspek ekonomi untuk memelihara keberlanjutan (sustainability) perusahaan itu sendiri. ISRA diharapkan dapat memotivasi perusahaan-perusahaan untuk menerapkan Sustainability Reporting. Berdasarkan Laporan ISRA 2014, Jumlah perusahaan yang menerbitkan laporan sustainability report (SR) semakin meningkat dari tahun ke tahun. Pada tahun 2007 tercatat hanya 15 perusahaan yang menerbitkan SR dan pada tahun 2014 jumlah tersebut meningkat menjadi 6o perusahaan

Perusahaan-perusahaan yang memenangkan Indonesia Sustainability Reporting Award (ISRA) akan mendongkrak citra perusahaan dimata publik, karena telah meraih penghargaan yang mengedepankan keselarasan antara aspek ekonomi, sosial dan lingkungan. Namun citra sebagai perusahaan yang beretika belum menjamin bahwa perusahaan tidak melakukan kegiatan yang tidak beretika dalam pelaporan keuangannya (Sari dan Sidharta, 2014).

Seiring dengan sudah banyak terlaksananya tuntutan akan tanggungjawab sosial perusahaan, mulai terdengar adanya modus atau tujuan lain dari tanggung jawab sosial perusahaan itu sendiri. Adanya tujuan lain dibalik pelaksanaan tanggung jawab sosial telah diteliti oleh Sari dan Sidharta (2014) yang menemukan bahwa manajer yang melakukan manipulasi laba akrual akan menggunakan tanggung jawab sosial atau CSR sebagai perilaku 
etis untuk memberikan sinyal yang akan mengalihkan perhatian pemegang saham dari isuisu yang bisa membuat manajer dihukum. Penelitian Prior et.al (2008) juga menemukan bahwa manajer yang memanipulasi pendapatan (earning management) menggunakan kegiatan tanggung jawab sosial perusahaan (CSR) sebagai salah satu strateginya untuk menjaga hubungan dengan para stakeholder.

Adanya praktek manajemen laba dapat mengurangi kepercayaan masyarakat terhadap pelaporan keuangan dan menghalangi kecekapan aliran modal di pasaran keuangan (Scot dan Marshal, 2001). Untuk dapat mengembalikan kepercayaan pihak pemakai laporan keuangan yang diantaranya adalah investor, kreditor ataupun pemakai lain sangat diharapkan kualitas audit yang baik. Kualitas audit baik akan menghasilkan laporan keuangan yang baik sehingga keputusan yang dibuat oleh pemakai laporan keuangan akan baik dan rasional.

Menurut Healy and Wahlen (1999) manajemen laba terjadi ketika para manajer menggunakan keputusan tertentu dalam laporan keuangan dan mengubah transaksi untuk mengubah laporan keuangan sehingga menghasilkan informasi yang menyesatkan.

Ketika manajer memutuskan untuk melakukan manajemen laba, mereka perlu memutuskan untuk melakukan manajemen laba di tingkat pendapatan domestik, pendapatan asing atau keduanya. Manajer diduga juga mempertimbangkan cost dan benefit saat akan melakukan manajemen laba seperti kecenderungan ketahuan serta kompensasi bonus yang akan didapat (El Mehdi dan Sebuoi, 2011).

Perusahaan besar dengan tingkat organisasi yang kompleks akan menyebabkan kompleksitas akuntansi yang tinggi pula. Kondisi ini berpotensi untuk menciptakan konflik keagenan dan menyebabkan adanya asimetri informasi. Namun semakin tinggi kompleksitas akuntansi yang disebabkan karena banyaknya jumlah anak perusahaan, akan mengurangi kecenderungan manajer yang melakukan manajemen laba untuk meningkatkan pengungkapan kegiatan CSR. Hal ini disebabkan karena dengan kompleksitas akuntansi yang semakin tinggi tersebut juga membuat manajer yakin bahwa tindakan manajemen labanya tidak bisa dideteksi oleh stakeholder. (Sari dan Sidharta, 2014).

Selain karena kompleksitas akuntansi, kurangnya pengawasan pada sistem pengendalian internal perusahaan, manajer dapat dengan mudah melakukan tindakan manajemen laba dan kecurangan dengan intervensi pada penyusunan laporan keuangan berdasarkan akuntansi akrual. Untuk itu perlu adanya komite audit yang diharapkan dapat meningkatkan kualitas laba dan kinerja perusahaan melalui pengawasan terhadap proses pelaporan keuangan dan pelaksanaan audit eksternal (Widiatmaja, 2010). Keberadaan Komite Audit menjadi sangat penting sebagai salah satu perangkat utama dalam penerapan good corporate governance dimana independensi, transparansi, akuntabilitas dan tanggungjawab, serta sikap adil menjadi prinsip dan landasan organisasi perusahaan. Kehadiran dari komite audit akan meningkatkan pengungkapan sukarela perusahaan. Komite audit dapat meminta direksi dan manajemen untuk memberikan informasi atas laporan keuangan lebih transparan dan mendorong untuk mengungkapkan informasiinformasi yang bersifat sukarela.

Penelitian ini merupakan pengembangan dari penelitian Sari dan Sidharta (2014), penelitian ini menambahkan variabel kualitas audit sebagai varaiabel anteseden dari manajemen laba. 


\section{KERANGKA TEORI DAN PENGEMBANGAN HIPOTESIS}

\section{Kualitas Audit dan Manajemen Laba}

Berdasarkan teori agensi, terjadi konflik antara principal dengan agen. Audit memiliki fungsi sebagai proses untuk mengurangi ketidakselarasan informasi yang terdapat antara manajer dan para pemegang saham dengan menggunakan pihak luar untuk memberikan pengesahan terhadap laporan keuangan. Para pengguna laporan keuangan terutama para pemegang saham akan mengambil keputusan berdasarkan pada laporan yang telah dibuat oleh auditor. Hal ini berarti auditor mempunyai peranan penting dalam pengesahan laporan keuangan suatu perusahaan. Oleh karena itu auditor harus menghasilkan audit yang berkualitas sehingga dapat mengurangi ketidakselarasan yang terjadi antara pihak manajemen dan pemilik. Ikatan Akuntan Indonesia (IAI) menyatakan bahwa audit yang dilakukan auditor dikatakan berkualitas, jika memenuhi standar auditing dan standar pengendalian mutu.

Kualitas audit yang baik akan mengurangi jumlah manajemen laba yang dilakukan perusahaan, karena audit yang berkualitas dilaksanakan dengan kemampuan teknologi tinggi, dilaksanakan dengan prosedur audit yang benar, dan menggunakan metode penyampelan yang benar, dan akan secara independen melaporkan pelanggaran tersebut (DeAngelo, 1981)

Penggunaan auditor berkualitas tinggi dapat mencegah emiten berlaku curang dalam menyajikan suatu laporan keuangan yang tidak relevan ke masyarakat. Becker et al. (1998) menyimpulkan bahwa perusahaan-perusahaan yang auditornya bukan KAP kelompok Big five melaporkan unexpected accruals yang secara signifikan menambah pendapatan jika dibandingkan dengan perusahaan yang auditornya berasal dari KAP kelompok Big five. Chen et al (2005) dalam penelitiannya menemukan bahwa klien dari auditor non-big four melaporkan discretionary accruals yang lebih tinggi dari yang dilaporkan oleh klien dari auditor big four. Penelitian yang dilakukan Gerayli at al (2011) membuktikan bahwa perusahaan yang diaudit oleh auditor big four menggunakan lebih sedikit manajemen laba. Penelitian-penelitian tersebut menunjukkan bahwa auditor Big four memiliki kemampuan untuk mendeteksi adanya praktek manajemen laba di dalam suatu perusahaan.

Berdasarkan penjelasan di atas, maka dapat dirumuskan hipotesis penelitian sebagai berikut:

\section{H1: Kualitas audit berpengaruh negatif terhadap manajemen laba.}

\section{Manajemen Laba dan Corporate Social Responsibility}

Menurut Healy and Wahlen (1999) manajemen laba terjadi ketika para manajer menggunakan keputusan tertentu dalam laporan keuangan dan mengubah transaksi untuk mengubah laporan keuangan sehingga menyesatkan stakeholder yang ingin mengetahui kinerja ekonomi yang diperoleh perusahaan atau untuk mempengaruhi hasil kontrak yang menggunakan angka-angka akuntansi yang dilaporkan dalam laporan keuangan.

Dalam hubungan antara principal dan agent terdapat suatu konflik kepentingan akibat dari tujuan yang berbeda antara principal dan agent. Pihak principal atau pemilik perusahaan tidak memiliki informasi yang cukup mengenai keadaan perusahaan dan kinerja manajer sedangkan agent atau manajer memiliki informasi yang lebih banyak terkait dengan kondisi perusahaan. Lebih lanjut lagi, dengan didorong adanya kepentingan yang berbeda maka manajer dapat memanfaatkan keadaan tersebut untuk melakukan manajemen laba terhadap laporan keuangan perusahaan sehingga tidak menunjukkan 
keadaan yang sesungguhnya. Akibatnya pemilik perusahaan tidak dapat melakukan pengambilan keputusan investasi secara optimal.

Ketika pemilik perusahaan atau shareholder menemukan indikasi terjadinya manajemen laba di dalam perusahaannya, maka nilai perusahaan langsung turun drastis di dalam pasar saham. Tentu saja hal tersebut akan berdampak sangat serius terhadap pemilik perusahaan dan stakeholder yang lainnya. Ketika hal tersebut terjadi, maka stakeholder akan melakukan aksi yang akan mengancam keberadaan manajemen.

Usaha yang memungkinkan dilakukan oleh manajer untuk mengamankan posisi mereka adalah dengan membuat dan melibatkan diri dalam kegiatan yang bertujuan untuk meningkatkan hubungan antara perusahaan dengan stakeholder dan lingkungan sosial masyarakat, dalam hal ini corporate social responsibility (CSR). Untuk menarik dukungan dari kelompok tersebut, kegiatan CSR yang biasa dilakukan adalah memasukkan aspek sosial ke dalam proses produksi, mengadopsi praktek pengembangan sumber daya manusia secara progresif meningkatkan kegiatan yang ramah lingkungan melalui kegiatan daur ulang dan pengurangan polusi dan limbah, atau dengan mempercepat tujuan dari organisasi masyarakat (McWilliams et al., 2006).

Dalam penelitian terdahulu yang dilakukan oleh Prior et.al (2008), menemukan bahwa manajer dalam perusahaan yang melakukan manajemen laba cenderung semakin aktif dalam meningkatkan citra dan menarik dukungan dari publik dan stakeholder melalui kebijakan CSR.Manajer percaya bahwa dengan memenuhi kepuasan stakeholder dan mewujudkan kesan yang baik terhadap lingkungan dan sosial maka kecurigaan dan kewaspadaan dari stakeholder dapat dikurangi sehingga kemungkinan untuk diamati oleh stakeholder yang sudah puas juga dapat dikurangi.

Berdasarkan literatur di atas, hipotesis yang dikembangkan adalah:

\section{H2: Manajemen laba berpengaruh positif terhadap pengungkapan corporate social responsibility}

\section{Kompleksitas Akuntansi Terhadap Manajemen Laba dan Pegungkapan CSR}

Kompleksitas akuntansi akan semakin tinggi bila perusahaan melakukan diversifikasi atau perusahaannya tersebar secara geografis. Beberapa riset telah menunjukkan bahwa perusahaan yang melakukan diversifikasi atau tersebar secara geografis memiliki manajemen laba yang tinggi. Berdasar hipotesis konflik keagenan kemampuan manajer untuk mendistorsi informasi dan memanipulasi laba sangat tergantung pada tingkat komplektisitas organisasi yang ada pada perusahaan (El Mehdi dan Seboui, 2011).

Kompleksitas akuntansi tidak hanya memotivasi manajer untuk melakukan manipulasi akuntansi tetapi juga membuat kondisi yang mendukung untuk membuat manajemen laba sulit dideteksi. Perusahaan dengan anak perusahaan yang banyak akan meningkatkan kompleksitas organisasi dan kemudian meningkatkan asimetri informasi antara manajer dan investor. Asimetri informasi seperti ini dapat membuka peluang melakukan manajemen laba karena investor mungkin tidak memiliki insentif, sumber daya dan akses yang cukup untuk memantau tindakan manajer (Warfield et al., 1995).

Kompleksitas akuntansi yang tinggi akan menyebabkan sulitnya pendektesian manajemen laba juga dapat dilihat dari hasil penelitian yang dilakukan oleh Cormier et al., (2013). Cormier et al. (2013) menyatakan bahwa kompleksitas akuntansi memperlemah hubungan antara manajemen laba dan asimetri informasi. Adanya kompleksitas akuntansi yang tinggi menyebabkan investor tidak dapat mendeteksi manajemen laba yang dilakukan perusahaan sehingga investor menyimpulkan bahwa tidak terjadi asimetri informasi.

Kompleksitas akuntansi perusahaan mempersulit deteksi manajemen laba oleh investor, maka kompleksitas akuntansi akan dapat memperlemah insentif perusahaan untuk melakukan pengungkapan CSR yang dimotivasi oleh keinginan untuk menutupi 
manajemen laba, karena kompleksitas akuntansi yang semakin tinggi tersebut membuat manajer yakin bahwa tindakan manajemen labanya tidak bisa dideteksi oleh stakeholder (Sari dan Sidharta, 2014).

Berdasarkan diskusi diatas, maka hipotesis yang dikembangkan adalah:

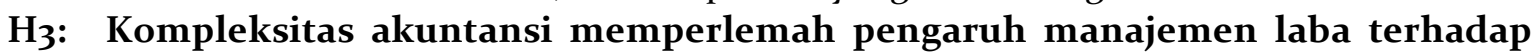
pengungkapan corporate social responsibility.

\section{Efektifitas Komite Audit Terhadap Manajemen Laba dan Pengungkapan CSR}

Peran komite audit dalam perusahaan diperjelas melalui empat karakteristik komite audit (Hermawan, 2009) yaitu independensi komite audit, aktivitas komite audit (rapat), ukuran (size) dari komite audit, dan komposisi dari komite audit. Komite audit yang efektif adalah komite audit yang memiliki cakupan tugas dan jumlah minimal rapat sesuai aturan Bapepam, kehadiran yang aktif, dan kompetensi keuangan. Tugas Komite Audit erat kaitannya dengan penelaahan terhadap risiko yang dihadapi perusahaan dan ketaatan peraturan yang berlaku. Keberadaan Komite Audit menjadi sangat penting sebagai salah satu perangkat utama dalam penerapan good corporate governance dimana independensi, transparansi, akuntabilitas dan tanggungjawab, serta sikap adil menjadi prinsip dan landasan organisasi perusahaan. Komite Audit juga akan bertanggung jawab untuk menelaah kepatuhan perusahaan terhadap UU dan peraturan yang berlaku. Kehadiran dari komite audit akan meningkatkan pengungkapan sukarela perusahaan. Komite audit dapat meminta direksi dan manajemen untuk memberikan informasi atas laporan keuangan lebih transparan dan mendorong untuk mengungkapkan informasi-informasi yang bersifat sukarela. Dengan tugas tersebut, maka komite audit seharusnya dapat menelaah pengungkapan CSR perusahaan. Dan dengan mekanisme ini maka diharapkan insentif melakukan pengungkapan CSR untuk menutupi manajemen laba akan semakin lemah.

Selain itu, komite audit juga dapat menjadi pengawas yang dapat memperbaiki kualiatas arus informasi antara perusahaan dan manajer dalam laporan keuangan, dimana keduanya mempunyai tingkat informasi yang berbeda. Keberadaan komite audit sebagai bagian dari corporate governance dapat meningkatkan relevansi dan reliabilitas pengungkapan informasi perusahaan. Sebagai bagian integrasi dari corporate governance komite audit diharapkan meningkatkan akuntabilitas dan transparansi dalam pelaksanaan serta pengungkapan informasi dalam laporan tahunan perusahaan. Penelitian sebelumnya telah banyak membuktikan bahwa keberadaan komite audit mempengaruhi kualitas laporan keuangan yang disajikan oleh perusahaan. Zhou dan Chen (2004) mengemukakan dalam penelitiannya pada bank-bank tentang pengaruh komite audit, board characteristics terhadap adanya manajemen laba bahwa ukuran komite audit, independensi komite audit, jumlah meeting, dan ukuran Board membatasi perusahaan melakukan manajemen laba pada bank-bank yang termasuk dalam manajemen laba tinggi.

Dalam penelitian Sun et al. (2010) dapat dijelaskan pula bahwa efektifitas komite audit yang diproksikan dengan frekuensi rapat komite audit mengurangi pengaruh manajemen laba terhadap corporate social responsibility. Keefektifan komite audit ini akan mengurangi intensitas perusahaan untuk melakukan manajemen laba dan akhirnya mengurangi hubungan manajemen laba dengan corporate social responsibility.

Berdasarkan pandangan di atas, hipotesis yang dikembangkan adalah:

H4: Efektifitas komite audit memperlemah pengaruh manajemen laba terhadap pengungkapan corporate social responsibility. 


\section{METODE PENELITIAN}

\section{Sampel Penelitian}

Penelitian ini mengambil sampel satu industri, yaitu perusahaan manufaktur yang terdaftar di BEI tahun 2013. Pemilihan satu jenis industri dimaksudkan untuk mendapatkan pola pengungkapan tidak jauh sberbeda (Botosan 1997). Sektor manufaktur dipilih karena merupakan sektor dengan jumlah perusahaan terbesar dibanding sektor lain yang terdaftar di BEI.

\section{Definisi Operasional Variabel dan Pengukuran Variabel Variabel Dependen}

Kegiatan CSR perusahaan tercermin dalam pengungkapan CSR dalam laporan tahunan. Untuk mengukur tingkat pengungkapan CSR, penelitian ini menggunakan indikator sebanyak 60 item yang dikembangkan berdasarkan penelitian Lanis dan Richardson (2012), Angelia dan Martani (2012) dan dimodifikasi oleh Sembiring (2005). Modifikasi dilakukan untuk menyesuaikan dengan kondisi di Indonesia (Sari dan Sidaharta,2014) Keseluruhan item terdiri dari 7 klasifikasi::

1. Strategi perusahaan dan CSR (7 item)

2. Strategi terkait tenaga kerja (20 item)

3. Investasi sosial ( 4 item)

4. Lingkungan (11 item)

5. Konsumen dan Pemasok (8 item)

6. Keterlibatan dalam komunitas dan politik (9 item)

7. Pengungkapan biaya CSR (1 item)

Untuk setiap item pengungkapan akan diberi skor 1 bila perusahaan mengungkapkan dan o bila perusahaan tidak mengungkapkan informasi tersebut. Tingkat pengungkapan CSR dihitung dengan menghitung persentase pengungkapan CSR untuk setiap klasifikasi, yaitu total skor dibagi dengan total item :

Pengungkapan CSR per klasifikasi = Total item yang diungkapkan perusahaan

Total item pengungkapan per klasifikasi

\section{Variabel Anteseden}

\section{Kualitas Audit}

Kualitas audit adalah seberapa baik audit mendeteksi dan melaporkan salah saji material dalam laporan keuangan. Aspek deteksi adalah refleksi dari kompetensi auditor, sedangkan pelaporan adalah refleksi etika atau integritas auditor, khususnya independensi (Arens et al ,2011:105).

Dimensi kualitas audit yang paling sering digunakan dalam penelitian adalah ukuran auditor. Pengukuran dari ukuran auditor menggunakan variabel dummy, nilai 1 jika perusahaan diaudit oleh auditor The big four, dan o jika lainnya, sesuai dengan penelitian Gerayli et al (2011). Kategori auditor Big Four di Indonesia, yaitu sebagai berikut:

a. KAP Price Waterhouse Coopers, yang bekerja sama dengan Tanudiredja, Wibisana \& rekan.

b. KAP KPMG (Klynveld Peat Marwick Goerdeler), yang bekerja sama dengan KAP Sidharta dan Wijaya.

c. KAP Ernest and Young, yang bekerja sama dengan KAP Purwantono, Suherman \& Surja.

d. KAP Deloitte Touche Thomatsu, yang bekerja sama dengan KAP Osman Bing Satrio \& Rekan. 


\section{Variabel Independen \\ Manajemen Laba}

Manajemen laba merupakan perilaku oportunistik manajer dalam melakukan tindakan diskresioner atas laba yang dilaporkan guna memaksimalkan keuntungan mereka sendiri. Menurut Sulistyanto (2008:48) Manajemen laba adalah upaya manajer perusahaan untuk mengintervensi atau mempengaruhi informasi-informasi dalam laporan keuangan dengan tujuan untuk mengelabui stakeholder yang ingin mengetahui kinerja dan kondisi perusahaan.

Manajemen laba menggunakan proksi discretionary accrual. Dalam penelitian ini manajemen laba diukur menggunakan model yang dikembangkan oleh Kothari et al.(2005).

Tahap-tahap penentuan discretionary accrual adalah seperti berikut:

(1) Menghitung total akrual dengan menggunakan pendekatan aliran kas (cash flow approach), yaitu :

$$
\text { TACCit }=\text { NIit }- \text { CFOit }(1)
$$

Keterangan:

TACCit = Total akrual perusahaan i pada tahun $\mathrm{t}$

NIit $\quad=$ Laba bersih kas dari aktivitas operasi perusahaan i pada periode ke $t$

CFOit $\quad=$ Aliran kas dari aktivitas operasi perusahaan i pada periode ke $t$

(2) Menentukan koefisien dari regresi akrual.

Akrual diskresioner merupakan perbedaan antara total akrual (TACC) dengan nondiscretionary accrual (NDACC). Langkah awal untuk menentukan nondiscretionary accrual yaitu dengan melakukan regresi sebagai berikut:

TACCit/TAit-1 $=\beta_{1}(1 /$ TAit-1 $)+\beta_{2}((\Delta$ REVit- $\Delta$ RECit $) /$ TAit-1 $)+\beta_{3}($ PPEit/TAit-1 $)+$ $\beta_{4}$ (ROAit-1/ TAit-1 )+ e (2)

Keterangan:

TACCit $=$ Total akrual perusahaan i pada tahun $\mathrm{t}$ (yang dihasilkan dari perhitungan nomor 1 di atas)

TA it-1 = Total aset perusahaan i pada akhir tahun $\mathrm{t}-1$

$\triangle$ REVit $\quad=$ Perubahan pendapatan perusahaan i pada tahun $\mathrm{t}$

$\triangle$ RECit $\quad=$ Perubahan piutang bersih (net receivable) perusahaan i pada tahun $\mathrm{t}$

PPEit $\quad=$ Property, plant and equipment perusahaan i pada tahun $\mathrm{t}$

ROAit-1 = Return on assets perusahaan i pada akhir tahun $\mathrm{t}-1$

(3) Menentukan nondiscretionary accrual.

Regresi yang dilakukan di (2) menghasilkan koefisien $\beta_{1}, \beta_{2}, \beta_{3}$ dan $\beta_{4}$. Koefisien $\beta_{1}, \beta_{2}$, $\beta_{3}$ dan $\beta_{4}$ tersebut kemudian digunakan untuk memprediksi nondiscretionary accrual melalui persamaan berikut:

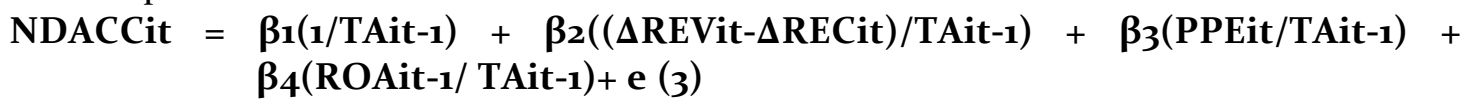

Keterangan:

NDACCit = Nondiscretionary accrual perusahaan i pada tahun $\mathrm{t}$

e $\quad$ Error

(4) Menentukan discretionary accrual.

Setelah didapatkan akrual nondiskresioner, kemudian discretionary accrual bisa dihitung dengan mengurangkan total akrual (hasil perhitungan di (1)) dengan nondiscretionary accrual (hasil perhitungan di (3)). 
Keterangan:

$$
\text { DACCit }=(\text { TACCit } / \text { TAit-1 })-\text { NDACCit }(4)
$$

DACCit = Discretionary accrual perusahaan i pada tahun $\mathrm{t}$

\section{Variabel Moderasi}

Kompleksitas Akuntansi

Kompleksitas akuntansi perusahaan merupakan salah karakteristik perusahaan yang dapat menambah suatu tantangan pada audit dan akuntansi. Tingkat kompleksitas akuntansi sebuah perusahaan bergantung pada jumlah dan alokasi unit operasinya serta diversifikasi jalur produk dan pasarnya.

Kompleksitas akuntansi pada penelitian ini mengacu pada penelitian Yaacob dan Che Ahmad (2012) yang diukur dengan jumlah anak perusahaan yang dimiliki oleh perusahaan. Perusahaan dengan jumlah anak perusahaan yang besar akan memiliki tingkat kompleksitas akuntansi yang tinggi pada saat konsolidasi laporan keuangan. Akibatnya, Perusahaan dengan anak perusahaan yang banyak meningkatkan kompleksitas organisasi dan kemudian meningkatkan asimetri informasi antara manajer dan investor.

\section{Efektivitas Komite Audit}

Komite audit yang efektif adalah komite audit yang memiliki cakupan tugas dan jumlah minimal rapat sesuai aturan Bapepam, kehadiran yang aktif, dan kompetensi keuangan. Pengukuran efektivitas komite audit menggunakan indeks yang dikembangkan oleh Hermawan (2009). Efektivitas komite audit diprediksi memperlemah hubungan antara manajemen laba dan CSR.

Skala penilaian adalah 1-3, yaitu 1 adalah poor, 2 adalah fair dan 3 adalah good. Indeks efektifitas komite audit terdiri dari 11 item yang dilihat dari tiga klasifikasi, yaitu efektifitas dari aktivitas komite audit (8 item), ukuran komite audit (1 item), dan kemampuan komite audit ( 2 item). Indeks komite audit untuk setiap klasifikasi dihitung dengan rumus:

KOMDIT per klasifikasi $=\quad$ Total Skor Perusahaan Total Skor Maksimum per klasifikasi

\section{Teknik Analisi Data}

Statistik inferensial yang digunakan dalam penelitian ini mengaplikasikan metode Structural Equation Model berbasis Partial Least Square (PLS) dengan bantuan Smart PLS 2.0 M3.

\section{HASIL DAN PEMBAHASAN}

\section{Pemilihan Sampel Penelitian}

Sampel dalam penelitian ini diperoleh dengan menggunakan metode purposive sampling, dimana pemilihan sampel yang diambil sesuai dengan kriteria sampel sesuai. Dari seluruh perusahaan manufaktur yang menjadi populasi, diperoleh 6o perusahaan yang memenuhi kriteria sampel.

\section{Statistik Deskriptif}

Statistik deskriptif data penelitian disajikan pada Tabel 1. Berdasarkan Tabel 1, ratarata pengungkapan CSR perusahaan adalah $43,42 \%$. Hal ini menunjukkan bahwa rata-rata pengungkapan CSR masih rendah. Dengan demikian walaupun terdapat fenomena 
meningkatnya CSR perusahaan-perusahaan di Indonesia beberapa tahun terakhir, namun ternyata masih belum komprehensif mencakup aspek-aspek yang terkait CSR. Untuk indikator yang bersifat kategori yaitu kualitas audit. Dari 6o perusahaan manufaktur yang dijadikan sampel, sebanyak $37 \%$ telah menggunakan auditor yang berasal dari KAP yang berafiliasi dengan KAP Big Four untuk menjadi auditor eksternal perusahaan. Untuk variabel kompleksitas akuntansi rata-rata jumlah anak perusahaan adalah 4,9. Dan ratarata skor efektifitas komite audit adalah $80 \%$. Hal ini menunjukkan bahwa rata-rata perusahaan sudah memenuhi aturan tentang tugas, jumlah rapat, kehadiran, dan kompetensi komite audit yang ditetapkan oleh BAPEPAM.

\section{Tabel 1 Statistik Deskriptif}

\begin{tabular}{|c|c|c|c|c|c|}
\hline Variabel & $\mathrm{N}$ & Minimum & Maximum & Mean & $\begin{array}{c}\text { Std. } \\
\text { Deviation }\end{array}$ \\
\hline CSR : & \multirow{10}{*}{60} & & & & \\
\hline $\begin{array}{l}\text { Strategi Tanggung } \\
\text { Jawab Sosial }\end{array}$ & & 0,4286 & 1,0000 & 0,5500 & 0,1362 \\
\hline Strategi & & 0,1000 & 0,8000 & 0,3642 & 0,1613 \\
\hline Ketenagakerjaan & & & & & \\
\hline Investasi Sosial & & 0,0000 & 1,0000 & 0,5542 & 0,2525 \\
\hline Lingkungan & & 0,0000 & 1,0000 & 0,3318 & 0,2269 \\
\hline Pelanggan \& Pemasok & & 0,1250 & 1,0000 & 0,6438 & 0,2276 \\
\hline Keterlibatan Dalam & & 0,0000 & 1,0000 & 0,4292 & 0,2163 \\
\hline $\begin{array}{l}\text { Komunitas } \\
\text { Biaya Tanggung Jawab }\end{array}$ & & 0,0000 & 1,0000 & 0,5000 & 0,5042 \\
\hline 80 - & & & & & \\
\hline
\end{tabular}

\begin{tabular}{|c|c|c|c|c|c|}
\hline Variabel & $\mathrm{N}$ & Minimum & Maximum & Mean & $\begin{array}{c}\text { Std. } \\
\text { Deviation }\end{array}$ \\
\hline Manajemen Laba & 60 & $-0,0195$ & 0,2809 & 0,0747 & 0,0584 \\
\hline Kompleksitas Akuntansi & 60 & 1,0000 & 19,0000 & 4,9000 & 4,4748 \\
\hline $\begin{array}{l}\text { Efektifitas Komite Audit: } \\
\text { Aktivitas Komite Audit } \\
\text { Ukuran Komite Audit } \\
\text { Expertise dan } \\
\text { Kompetensi }\end{array}$ & 60 & $\begin{array}{l}0,5833 \\
0,3333 \\
0,3333\end{array}$ & $\begin{array}{l}0,9583 \\
1,0000 \\
1,0000\end{array}$ & $\begin{array}{r}0,8111 \\
0,6778 \\
0,8472\end{array}$ & $\begin{array}{r}0,0972 \\
0,1222 \\
0,1948\end{array}$ \\
\hline $\begin{array}{l}\text { Kualitas Audit : } \\
\text { KAP Big Four } \\
\text { KAP Non Big Four }\end{array}$ & $\begin{array}{l}22 \\
38 \\
\end{array}$ & & $\begin{array}{l}0,37 \\
0,63 \\
\end{array}$ & & \\
\hline
\end{tabular}

\section{Hasil Analisis Data}

Pengolahan data dengan PLS memerlukan dua tahap penilaian untuk menilai fit model dari model tersebut. Tahap-tahap tersebut adalah outer model dan inner model.

\section{Model Pengukuran (Outer Model)}

\section{Uji Validitas}

Outer model dengan indikator reflektif dievaluasi melalui analisis faktor konfimatori yang menggunakan pendekatan MTMM (MultiTrait-MultiMethod) dengan menguji 
validitas convergent dan validitas discriminant (Campbell dan Fiske dalam Latan dan Ghozali, 2012:78).

\section{Validitas Convergent}

Seluruh indikator pada konstruk dalam penelitian memiliki nilai loading diatas o,70. Hal ini menjelaskan bahwa seluruh indikator yang ada pada seluruh konstruk dalam penelitian ini memenuhi persyaratan validitas convergent. Sementara itu, Nilai AVE dan Communality yang dihasilkan oleh semua konstruk dalam penelitian ini memiliki nilai diatas 0,50 . Hal ini menjelaskan bahwa seluruh konstruk dalam penelitian ini memenuhi persyaratan validitas convergent.

\section{Validitas Discriminant}

Hasil uji validitas discriminant dilakukan dengan membandingkan nilai akar kuadrat AVE dan korelasi antar konstruk dapat dilihat pada tabel 2

Tabel 2 : Perbandingan Nilai Kuadrat AVE dengan

Korelasi Antar Konstruk

\begin{tabular}{|c|c|c|c|c|c|c|c|c|c|}
\hline & CSR & EKA & KA & KPA & MLB & $\begin{array}{c}\text { MLB * } \\
\text { EKA }\end{array}$ & $\begin{array}{c}\text { MLB * } \\
\text { KPA }\end{array}$ & AVE & $\sqrt{ }$ AVE \\
\hline CSR & 1 & & & & & & & 0,5407 & 0,7353 \\
\hline EKA & $\mathrm{o}, 4187$ & 1 & & & & & & 0,6088 & 0,7803 \\
\hline KA & 0,4887 & $\begin{array}{c}0,38 \\
65\end{array}$ & 1 & & & & & 1 & 1 \\
\hline & CSR & EKA & KA & KPA & MLB & $\begin{array}{c}\text { MLB * } \\
\text { EKA }\end{array}$ & $\begin{array}{c}\text { MLB * } \\
\text { KPA }\end{array}$ & AVE & $\sqrt{ } \mathrm{AVE}$ \\
\hline KPA & 0,3445 & 0,1667 & 0,3289 & 1 & & & & 1 & 1 \\
\hline MLB & $\begin{array}{c}- \\
0,1722\end{array}$ & $-0,1015$ & $\begin{array}{c}- \\
0,3934\end{array}$ & 0,0618 & 1 & & & 1 & 1 \\
\hline $\begin{array}{l}\text { MLB * } \\
\text { EKA }\end{array}$ & $\begin{array}{c}- \\
0,1450\end{array}$ & 0,0271 & $\begin{array}{c}- \\
0,3496\end{array}$ & 0,0934 & 0,9874 & 1 & & 0,9773 & 0,9885 \\
\hline $\begin{array}{l}\text { MLB * } \\
\text { KPA }\end{array}$ & 0,1553 & o,o679 & 0,1097 & o,8779 & 0,3976 & 0,4165 & 1 & 1 & 1 \\
\hline
\end{tabular}

Sumber : Data Olahan Smart PLS 2.o M3 (2015)

Pada tabel 2 tersebut dapat dilihat bahwa nilai akar kuadrat dari AVE lebih besar dibandingkan dengan nilai korelasi antar konstruk laten pada kolom yang sama. Hal ini menjelaskan bahwa seluruh konstruk yang ada dalam model penelitian ini memenuhi persyaratan validitas discriminant.

\section{Uji Reliabilitas}

Nilai composite reliability yang dihasilkan dalam penelitian ini adalah $\geq 0,70$ sehingga dapat dikatakan bahwa semua konstruk dapat dikatakan reliabel. Hasil uji reliabilitas dalam penelitian ini dapat dilihat pada tabel 3 . 
Tabel 3 : Nilai Composite Reliability

\begin{tabular}{|l|r|}
\hline & $\begin{array}{l}\text { Composite } \\
\text { Reliability }\end{array}$ \\
\hline CSR & 0,891011 \\
\hline EKA & 0,756503 \\
\hline KA & 1 \\
\hline KPA & 1 \\
\hline MLB & 1 \\
\hline MLB * EKA & 0,988526 \\
\hline MLB * KPA & 1 \\
\hline
\end{tabular}

Sumber : Data Olahan Smart PLS 2.0 M3 (2015)

\section{Model Struktural (Inner Model)}

Model struktural dinilai dengan melihat nilai R-Squares untuk setiap variabel laten endogen sebagai kekuatan prediksi dari model struktural. Hasil R-Squares dengan menggunakan SmartPLS 2.0 M3 dapat dilihat pada tabel dibawah ini:

Tabel 4 : Nilai R Square

\begin{tabular}{|l|r|}
\hline & R Square \\
\hline CSR & 0,415279 \\
\hline EKA & \\
\hline KA & \\
\hline KPA & 0,154776 \\
\hline MLB & \\
\hline MLB * EKA & \\
\hline MLB * KPA & \\
\hline
\end{tabular}

\section{Hasil Pengujian Hipotesis}

Tabel 5 berikut ini menampilkan nilai Path Coefficients (Mean, STDEV, T-Values), nilai ini digunakan untuk melihat apakah hipotesis yang diajukan dalam penelitian ini dapat diterima ataupun ditolak.

Tabel 5 : Hasil Path Coefficients (Mean, STDEV, T-Values)

\begin{tabular}{|l|r|r|r|r|r|}
\hline & $\begin{array}{c}\text { Original } \\
\text { Sample (O) }\end{array}$ & $\begin{array}{c}\text { Sample } \\
\text { Mean (M) }\end{array}$ & $\begin{array}{c}\text { Standard } \\
\text { Deviation } \\
\text { (STDEV) }\end{array}$ & $\begin{array}{c}\text { Standard } \\
\text { Error } \\
\text { (STERR) }\end{array}$ & $\begin{array}{c}\text { T Statistics } \\
(\mid \text { O/STERR })\end{array}$ \\
\hline $\begin{array}{l}\text { EKA -> } \\
\text { CSR }\end{array}$ & 0,764808 & 0,687957 & 0,213048 & 0,213048 & 3,589845 \\
\hline $\begin{array}{l}\text { KA -> } \\
\text { MLB }\end{array}$ & $-0,39342$ & $-0,40011$ & 0,078557 & 0,078557 & 5,008063 \\
\hline $\begin{array}{l}\text { KPA -> } \\
\text { CSR }\end{array}$ & 0,820189 & 0,77047 & 0,317838 & 0,317838 & 2,580527 \\
\hline $\begin{array}{l}\text { MLB -> } \\
\text { CSR }\end{array}$ & 3,460877 & 2,913853 & 1,577712 & 1,577712 & 2,193605 \\
\hline $\begin{array}{l}\text { MLB * } \\
\text { EKA -> }\end{array}$ & $-3,42382$ & $-2,81771$ & 1,699848 & 1,699848 & 2,014194 \\
\hline
\end{tabular}




\begin{tabular}{|l|r|r|r|r|r|}
\hline & $\begin{array}{c}\text { Original } \\
\text { Sample (O) }\end{array}$ & $\begin{array}{c}\text { Sample } \\
\text { Mean (M) }\end{array}$ & $\begin{array}{c}\text { Standard } \\
\text { Deviation } \\
\text { (STDEV) }\end{array}$ & $\begin{array}{c}\text { Standard } \\
\text { Error } \\
(\text { STERR })\end{array}$ & $\begin{array}{c}\text { T Statistics } \\
(\mid \text { O/STERR } \mid)\end{array}$ \\
\hline CSR & & & & & \\
\hline $\begin{array}{l}\text { KLB } \\
\text { KPA }-> \\
\text { CSR }\end{array}$ & $-0,56655$ & $-0,49338$ & 0,313422 & 0,313422 & 1,807624 \\
\hline
\end{tabular}

Sumber: hasil pengolahan data PLS

Hipotesis pertama yang diajukan dalam penelitian ini adalah untuk menguji pengaruh Kualitas Audit terhadap Manajemen Laba. Dari tabel 4 diatas dapat dilihat Kualiats Audit berpengaruh negatif terhadap manajemen laba $(\beta=-0,39342 t=5,008063$ $\mathrm{p}<\mathrm{o}, \mathrm{oo})$. Hasil ini mendukung penelitian Gerayli et al. (2011).

Hasil penelitian Gerayli et al. (2011) menemukan bahwa ukuran auditor yang merupakan proksi kualitas audit berhubungan negatif dengan earnings management yang diukur dengan discretionary accrual, sehingga menunjukkan bahwa perusahaan yang menggunakan auditor big 4 maka earning management di perusahaan akan lebih rendah dibandingkan dengan perusahaan yang di audit oleh auditor non big 4. KAP big 4 lebih memiliki sumber daya yang besar untuk meningkatkan kualitas audit. KAP big 4 juga dianggap lebih memiliki keahlian dan insentif sehingga dapat mempengaruhi dan membatasi tindakan manajemen laba yang dilakukan oleh manajemen. Ketika auditor mampu memberikan kualitas audit yang baik, manajemen akan terpaksa menghentikan praktik manajemen laba akrual yang dilakukannya karena perusahaan terancam tidak memperoleh opini auditor wajar tanpa pengecualian apabila tetap melakukan praktik manajemen laba akrual tersebut.

Hipotesis kedua yang diajukan dalam penelitian ini adalah untuk menguji pengaruh Manajemen Laba terhadap Pengungkapan CSR. Dari tabel 5 diatas dapat dilihat bahwa manajemen laba berpengaruh positif terhadap pengungkapan CSR $(\beta=3,460877 \mathrm{t}=\mathbf{2 , 1 9 3 6 0 5}$ $\mathrm{p}<\mathrm{o}, \mathrm{oo})$. Artinya perusahaan yang melakukan manajemen laba cenderung melakukan pengungkapan CSR yang tinggi. Perusahaan yang melakukan manajemen laba memiliki insentif untuk menutupi manajemen laba dengan membentuk citra yang baik di mata stakeholder.

Hal ini sesuai dengan teori sinyal yang terkait dengan pengungkapan CSR, yaitu bahwa dengan menyajikan pengungkapan CSR yang tinggi, perusahaan berusaha menunjukkan kepada stakeholder bahwa perusahaan memiliki kemampuan keuangan yang baik sehingga mampu melakukan kegiatan CSR yang tinggi. Dengan sinyal tersebut diharapkan stakeholder tidak mendeteksi bahwa dalam pelaporan keuangan perusahaan melakukan manajemen laba. Dengan demikian dapat disimpulkan bahwa manajemen laba yang dilakukan perusahaan merupakan salah satu motif untuk melakukan pengungkapan CSR. Hasil ini mendukung hasil penelitian Prior et al. (2008). Prior (2008) menemukan bahwa manajer akan cenderung semakin aktif meningkatkan citra dan menarik dukungan dari publik dan stakeholder melalui kegiatan CSR yang dibuktikan dengan pengungkapan dalam laporan tahunan. Sedangkan untuk perusahaan yang diduga tidak terlibat manipulasi laba tidak memiliki motif tersebut sehingga pengungkapan CSR nya lebih rendah dibanding perusahaan yang diduga melakukan manipulasi laba.

Hipotesis ketiga yang diajukan dalam penelitian ini adalah untuk menguji apakah kompleksitas akuntansi memoderasi pengaruh manajemen laba terhadap pengungkapan CSR. Hasil pengujian hipotesis ketiga menerima hipotesis ketiga yang menyatakan bahwa kompleksitas akuntansi memperlemah pengaruh manajemen laba terhadap pengungkapan $\operatorname{CSR}(\beta=-0,56655 \mathrm{t}=1,807624 \mathrm{P}<0,00)$. 
Dari sudut pandang manajer, pengungkapan CSR dapat digunakan sebagai alat untuk memberikan sinyal yang akan mengalihkan perhatian pemegang saham dari isu-isu yang bisa membuat manajer dihukum. Tindakan pencitraan ini semakin kuat ketika perusahaan melakukan manajemen laba (Sun et al., 2010).

Kompleksitas akuntansi yang tinggi menyebabkan manajemen laba yang dilakukan perusahaan yang terdiversifikasi menjadi lebih sulit terdeteksi karena investor mungkin tidak memiliki insentif, sumber daya dan akses yang cukup untuk memantau tindakan manajer. Cormier et al. (2013) menyatakan bahwa kompleksitas akuntansi memperlemah hubungan antara manajemen laba dan asimetri informasi. Adanya kompleksitas akuntansi yang tinggi menyebabkan investor tidak dapat mendeteksi manajemen laba yang dilakukan perusahaan sehingga investor menyimpulkan bahwa tidak terjadi asimetri informasi.

Oleh karena kompleksitas akuntansi perusahaan mempersulit deteksi manajemen laba oleh investor, maka kompleksitas akuntansi akan dapat mengurangi motivasi manajer mengungkapkan CSR perusahaan untuk menutupi manajemen. Hasil ini konsisten dengan penelitian Sari dan Sidharta (2014) yang menemukan kompleksitas akuntansi perusahaan mempersulit deteksi manajemen laba oleh investor, maka kompleksitas akuntansi akan dapat memperlemah insentif perusahaan untuk melakukan pengungkapan CSR yang dimotivasi oleh keinginan untuk menutupi manajemen laba, karena kompleksitas akuntansi yang semakin tinggi tersebut membuat manajer yakin bahwa tindakan manajemen labanya tidak bisa dideteksi oleh stakeholder.

Hipotesis keempat yang diajukan dalam penelitian ini adalah untuk menguji apakah efektifitas komite audit memoderasi pengaruh manajemen laba terhadap pengungkapan CSR. Dari tabel 4 diatas dapat dilihat bahwa efektifitas komite audit memperlemah pengaruh manajemen laba terhadap pengungkapan $\operatorname{CSR}(\beta=-3,42382 \mathrm{t}=2,014194 \mathrm{p}<0,00)$ Hasil ini mendukung hasil penelitian Sun et al (2010). Dalam penelitian Sun et al. (2010), frekuensi rapat komite audit mengurangi pengaruh manajemen laba terhadap corporate social responsibility. Sun et al. (2010) menjelaskan bahwa keefektifan komite audit akan mengurangi intensitas perusahaan untuk melakukan manajemen laba dan akhirnya mengurangi hubungan manajemen laba dengan corporate social responsibility.

Kehadiran dari komite audit juga akan meningkatkan pengungkapan sukarela perusahaan. Komite audit dapat meminta direksi dan manajemen untuk memberikan informasi atas laporan keuangan lebih transparan dan mendorong untuk mengungkapkan informasi-informasi yang bersifat sukarela Dengan tugas tersebut, maka komite audit dapat menelaah pengungkapan CSR perusahaan. Dan mekanisme ini insentif melakukan pengungkapan CSR untuk menutupi manajemen laba akan semakin lemah.

\section{SIMPULAN}

Penelitian ini ingin menguji apakah pengungkapan CSR yang dilakukan oleh perusahaan bermaksud untuk menutupi kegiatan management laba. Penelitian ini juga menguji apakah kompleksitas akuntansi dan efektifitas komite audit dapat memperlemah hubungan antara manajemen laba dan pengungkapan CSR. Selain itu, penelitian ini juga bertujuan untuk menguji pengaruh kualitas audit dan kompleksitas akuntansi terhadap manajemen laba. Penelitian ini dapat membuktikan bahwa kualitas audit dapat mengurangi kecenderuangan manajemen laba. Manajemen laba akrual cenderung akan terbatasi karena kualitas audit yang baik lebih mampu mendeteksi praktik manajemen laba akrual. Ketika auditor mampu memberikan kualitas audit yang baik, manajemen akan terpaksa menghentikan praktik manajemen laba.

Penelitian ini juga menunjukkan bahwa manajemen laba berpengaruh positif terhadap pengungkapan CSR perusahaan. Artinya, kecenderungan perusahaan untuk menutupi manajemen laba merupakan salah satu motif untuk melakukan pengungkapan 
CSR yang tinggi. Semakin tinggi manajemen laba perusahaan maka akan semakin tinggi pengungkapan CSR diperusahaan tersebut. Hasil penelitian ini juga menunjukkan pengaruh variabel pemoderasi, kompleksitas akuntansi memperlemah pengaruh manajemen laba terhadap pengungkapan CSR. Artinya, ketika kompleksitas akuntansi bertambah, perusahaan cenderung untuk mengurangi pengungkapan CSR perusahaan karena stakeholder mengalami kesulitan untuk mendeteksi manajemen laba yang dilakukan manajer.

Adanya efektifitas komite audit juga akan memperlemah pengaruh manajemen laba terhadap pengungkapan CSR. Keefektifan komite audit akan meningkatkan pengungkapan CSR perusahaan dan mengurangi intensitas perusahaan untuk melakukan manajemen laba dan akhirnya mengurangi hubungan manajemen laba dengan pengungkapan CSR.

\section{PUSTAKA ACUAN}

Angelia, P.H.A. dan D. Martani. 2012. Analysis the Impact of Corporate Sosial Responsibility Disclosure to Tax Aggressiveness. Paper presented at International Accounting Conference, Jakarta.

Arens, A. A., M. S. Beasley and R. J. Elder. 2008. Auditing and Assurance Service: An Integrated Approach. Ed.12. Jakarta: Erlangga.

Arens, A. A., et al. 2011. Auditing, Assurance Services E Ethics in Australia,An Integrated Approach. 8th edition Pearson Australia.

Becker, C., M. Defond, J. Jiambolvo dan K.R. Subramanyam. 1998. The effect of Audit on The Quality of Earning Management. Contemporary Accounting Research. Vol. 15

Botosan, C.A. 1997. Disclosure Level and The Cost of Equity Capital. The Accounting Review Vol.7, No.3, July $1997: 323-349$

Brammer, S. and Pavelin, S. 2006. Corporate Reputation and Social Performance: The Importance of Fit. Journal of Management Studies, 43(3), 435-455.

Chen, K. Y., Kuen Lin Lin, dan J. Zhou. 2005. Audit Quality and Earnings Management for Taiwan IPO Firm. Managerial Auditing Journal,Vol.20,No. 1, hal 86-104

Cormier, D., S. Hole, M. J. Ledoux. 2013. The Incidence of EarningsManagement on Information Assymetry in an Uncertain Environtment: Some Canadian Evidence. Journal of International Accounting, Auditing and Taxation.

DeAngelo, L. E. (1981). Auditor Size and Audit Quality, Journal of Accounting and Economics, 3, 183-199.

El Mehdi, I.K., S. Seboui. 2011. Corporate diversification and earnings management. Review of Accounting and Finance, 10 (2), 176-196.

Gerayli, M.S., A. R. Ma'atofa, and A.M. Yanesari. 2011. Impact of audit quality on Earnings Management : From Iran. International Research Journal of Finance and Economics, Issue 66, pp. 77-84. www.eurojournals.com/IRJFE 66 o7.

Ghozali, I dan H. Latan. 2012. Partial Least Square "Konsep, Teknik dan Aplikasi" SmartPLS 2.o M3. Semarang : Badan Penerbit Universitas Diponegoro.

Heally, P. M., and J.M. Wahlen 1999. A Review of he Earnings Management Literature and its Implication for Standard Setting, Accounting Horizon (December), p 365-383

Hermawan, A. A. 2009. The Influence of Board of Commissioners Effectiveness and Audit Committee Effectiveness, Family Ownership, Bank Monitoring Towards Contents of Earnings Information. Dissertation of Faculty of Economic, University of Indonesia

Kothari, S.P, et al. 2005. Performance Matched Discretionary Accrual Measures, Journal of Accounting and Economics,39(2), 163-197.

Lanis, R. and G. Richardson. 2012. Corporate social responsibility and tax aggressiveness: An empirical analysis. J. Account. Public Policy 31, 86-108 
McWilliams, A., D. S. Siegel, and P. M. Wright. 2006. Corporate social responsibility: Strategic implications, Journal of Management Studies, 43: 1-18.

National Center for Sustainability Reporting. 2014. Report of The Judges ISRA 2014.

Prior, D., J. Surroca and J.A. Tribo. 2008. Are socially responsible managers really ethical? Exploring the relationship between earnings management and corporate social responsibility, Corporate Governance : An International Review 16(3): 443-459.

Sari, D. dan S. Utama, 2014. Manajemen Laba Dan Pengungkapan CSR Dengan Kompleksitas Akuntansi Dan Efektifitas Komite Audit Sebagai Variabel Pemoderasi. Kumpulan Makalah, Simposium Nasional Akuntansi (SNA) XVII, Lombok.

Scott dan Marshal. (2001). Auditors and Earnings Management. CPA Journal 71: 39 - 45.

Sembiring, E. 2005. Karakteristik Perusahaan dan Pengungkapan tanggung Jawab Sosial : Study Empiris Pada Perusahaan yang tercatat di Bursa Efek Jakarta. Simposium Nasional A kuntansi VIII, Solo.

Sulistyanto, S. 2008. Manajemen Laba: Teori Dan Model Empiris. Jakarta: Grasindo

Sun, N., A. Salama, K. Hussainey, and M. Habbash. 2010. Corporate environmental, disclosure, corporate governance, and earnings management. Managerial Auditing Journal, 25 (77), 679-700

Thomas, W., D. Herrman and T. Inoue. 2004. Earnings Management through Affiliated Transactions, Journal of International Accounting Research, Vol. 3, pp. 1-25.

Warfield, T., J. Wild,, and K. Wild, 1995. Managerial Ownership, Accounting Choices, and Informativeness of Earnings, Journal of Accounting and Economics 20, 55-100.

Widiatmaja, B.F. 2010. Pengaruh Mekanisme Corporate Governance Terhadap Manajemen Laba Dan Konsekuensi Manajemen Laba Terhadap Kinerja Keuangan (Studi Pada Perusahaan Manufaktur Tahun 2006-20o8). Skripsi, Universitas Diponegoro, Semarang.

Yacoob, N. M. 2012. Adoption of IFRS and Audit Delay in Malaysia. International Journal of Economics and Finance. Vol 4, pp 167-176

Zhou, J. dan R. Elder. 2004. Audit Quality and Earnings Management by Seasoned Equity Offering Firms. Asia Pacific Journal of Accounting and Economics 11 (2): 95-120

Zhou, J. dan K.Y. Chen. 2004. Audit committee, board characteristics and earnings management by commercial banks. Working Paper.http://www.ssrn.com 